\title{
Pengaruh Fasilitas KeSEHATAN DAN FAKTOR SOSIO-EKONOMI TERHADAP Derajat Kelangsungan Hidup anak melalui Pemodelan PersamaAn TERSTUKTUR
}

\author{
${ }^{1}$ Nusar Hajarisman, ${ }^{2}$ Yayat Karyana, ${ }^{3}$ Dewi Rosiana \\ 1,2 Program Studi Statistika, Universitas Islam Bandung \\ ${ }^{3}$ Fakultas Psikologi, Universitas Islam Bandung \\ Email :'nusarhajarisman@yahoo.com, ${ }^{2}$ yayatkaryana@gmail.com, \\ 3ewirosiana@yahoo.com
}

\begin{abstract}
Abstrak. Tujuan dari penelitian ini adalah untuk mengetahui pengaruh dari fasilitas kesehatan dan faktor sosial ekonomi terhadap derajat kelangsungan hidup anak tingkat desa/kelurahan di Kabupaten Bandung, Provinsi Jawa Barat. Derajat kelangsungan hidup anak itu sendiri diukur melalui angka kematian bayi (AKB), angka kematian anak (AKA), dan status gizi anak (SGA). Oleh karena variabelvariabel yang diamati dalam penelitian ini berbentuk variabel laten, maka analisis dilakukan dengan menggunakan pemodelan persamaan terstruktur (atau dengan dikenal dengan istilah structural equation modeling, SEM). Hasil dari penelitian ini menunjukkan bahwa Faktor yang memberikan pengaruh secara langsung yang terbesar terhadap derajat kelangsungan hidup anak adalah fasilitas kesehatan (dengan nilai koefisien sebesar 0.8922) sebesar 79.60\%. Sedangkan dimensi faktor sosio-ekonomi memberikan pengaruh secara langsung yang relatif cukup kecil terhadap derajat kelangsungan hidup anak hanya sebesar 5.89\% (nilai koefisien sebesar 0.2426). Hasil-hasil yang diharapkan dari penelitian ini nantinya dapat digunakan sebagai dasar kebijakan Pemprov Jabar dalam meningkatkan kualitas sumber daya manusia dimasa yang akan datang.
\end{abstract}

Kata Kunci: angka kematian bayi, angka kematian anak, pemodelan persamaan terstruktur, variabel laten.

\section{Pendahuluan}

Pembangunan kesehatan merupakan bagian yang tidak terpisahkan dari pembangunan nasional. Derajat kesehatan suatu negara dapat dilihat dari indikator utama, yaitu Angka Kematian Bayi (AKB), Angka Kematian Ibu (AKI), serta Status Gizi Anak (SGA). Ketiga indikator tersebut merupakan indikator penting dalam menentukan tingkat kesehatan masyarakat, khususnya dalam mengukur derajat kelangsungan hidup anak (Bappenas, 2009). Keberhasilan pembangunan kesehatan berperan penting dalam meningkatkan mutu kualitas sumber daya manusia suatu negara. Pembangunan bidang kesehatan diarahkan untuk mencapai komitmen internasional yang dituangkan dalam Millennium Development Goals (MDGs). Salah satu tujuan MDGs adalah menurunkan angka kematian anak. Di Indonesia, Badan Pusat Statistik mencatat angka kematian bayi (AKB) menurun dari 39.6 per 1000 kelahiran hidup pada tahun 2004 menjadi 31.41 per 1000 kelahiran hidup tahun 2008 (BPS, 2007). Angka kematian ini turun menjadi 31.28 pada tahun 2010. Namun AKB ini masih tergolong tinggi karena masih jauh dari target MDGs tahun 2015 sebesar 23 per 1.000 sehingga bisa dikatakan bahwa upaya penurunan angka kematian bayi di Indonesia belum maksimal (Bappenas, 2010). Penurunan AKB mengindikasikan peningkatan derajat kesehatan masyarakat sebagai salah satu wujud keberhasilan pembangunan di bidang kesehatan. 


\section{4 | Nusar Hajarisman, et al.}

Tingginya angka kematian bayi dan balita tidak dapat dibiarkan begitu saja, mengingat kelangsungan hidup anak sangat menentukan kualitas sumber daya manusia di masa yang akan datang. Oleh karena itu, diperlukan intervensi yang tepat untuk mengurangi angka kematian tersebut. Intervensi yang efektif hanya dapat dilakukan, jika diketahui faktor-faktor signifikan yang mempengaruhi kelangsungan hidup anak. Studi empiris di negara sedang berkembang lain, seperti India dan Kenya, mengenai kelangsungan hidup anak, menunjukkan bahwa tidak hanya faktor di dalam sektor kesehatan, seperti jumlah puskesmas, bidan, dan infrastruktur kesehatan yang mempengaruhi kelangsungan hidup anak, tetapi juga faktor di luar sektor kesehatan, yaitu faktor sosial-ekonomi seperti tingkat pendidikan orang tua dan tingkat pendapatan rumah tangga.

Status sosial ekonomi menggambarkan tingkat penghidupan seseorang atau keluarga yang ditentukan oleh unsur pendidikan, pekerjaan dan penghasilan. Status ekonomi juga berkaitan dengan konsumsi (pengeluaran) dan produksi (pendapatan). Indikator status ekonomi bisa diukur melalui berbagai cara antara lain dengan menghitung tingkat pengeluaran perkapita. Status ekonomi mempengaruhi kebutuhan seseorang karena menentukan kemampuan keluarga untuk memperoleh makanan, karena pemenuhan kebutuhan hidupnya tergantung dari penghasilannya. Juga berpengaruh terhadap penyediaan bahan pangan, baik kuantitas maupun kualitas. Keluarga dengan status ekonomi rendah kemampuan untuk mempengaruhi konsumsi makanan keluarga yang berkaitan erat dengan status gizi keluarga.

Beberapa teori dan studi empiris menggambarkan kesehatan sebagai fungsi produksi, yang menunjukkan adanya hubungan struktural antara outcomes kesehatan dengan variabel-variabel perilaku rumah tangga, seperti pemberian nutrisi, pemberian ASI, pengaturan jarak kelahiran, dan sebagainya. Sejalan dengan hal tersebut, terdapat keterkaitan antara faktor sosial ekonomi dengan kelangsungan hidup anak. Salah satu teori yang paling banyak digunakan dalam permasalahan ini adalah sebagaimana yang dijelaskan oleh Mosley \& Chen (1984), serta Filmer (2003).

Mosley dan Chen (1984) membagi variabel-variabel yang berpengaruh terhadap kelangsungan hidup anak menjadi dua, yaitu; (1) Variabel yang dianggap eksogenous atau sosial ekonomi (seperti budaya, sosial, ekonomi, masyarakat, dan faktor regional) dan; (2) Variabel endogenous atau faktor biomedical (seperti pola pemberian ASI, kebersihan, sanitasi dan nutrisi).

Sementara itu, Filmer (2003) juga menjelaskan mengenai faktor-faktor sosial ekonomi sebagai penyebab kematian anak. Tingkat kematian anak dan nutrisi anak dipengaruhi oleh sisi permintaan dan penawaran. Sisi permintaan di sini adalah perilaku atau karakteristik rumah tangga dan individual seperti sanitasi, tindakan pencegahan penyakit dalam keluarga, pendapatan, pendidikan dan pengetahuan orang tua. Semakin baik sanitasi, tindakan pencegahan penyakit dalam keluarga, pendapatan, pendidikan dan pengetahuan orang tua, maka semakin rendah kematian anak dan semakin baik nutrisi anak.

Berdasarkan pemikiran di atas, maka tujuan dari penelitian ini adalah untuk mengetahui pengaruh dari fasilitas kesehatan dan faktor sosial ekonomi terhadap derajat kelangsungan hidup anak tingkat desa/kelurahan di Kabupaten Bandung, Provinsi Jawa Barat. Derajat kelangsungan hidup anak itu sendiri diukur melalui angka kematian bayi (AKB), angka kematian anak (AKA), dan status gizi anak (SGA). Oleh karena variabelvariabel yang diamati dalam penelitian ini berbentuk variabel laten, maka analisis dilakukan dengan menggunakan pemodelan persamaan terstruktur (atau dengan dikenal 
dengan istilah structural equation modeling, SEM). Hasil-hasil yang diharapkan dari penelitian ini nantinya dapat digunakan sebagai dasar kebijakan Pemprov Jabar dalam meningkatkan kualitas sumber daya manusia dimasa yang akan datang.

\section{Metode Penelitian}

\subsection{Data dan Sumber Data}

Data yang digunakan dalam penelitian ini adalah Pendataan Potensi Desa (Podes) Tahun 2011 yang dilakukan oleh Badan Pusat Statistik (BPS). Pendataan Podes merupakan kegiatan lanjutan yang telah telah dilaksanakan sejak tahun 1980 bersamaan dengan penyelenggaraan Sensus Penduduk 1980. Pengumpulan data Podes dilakukan sebanyak 3 (tiga) kali dalam kurun waktu 10 tahun, sebagai bagian dari rangkaian kegiatan Sensus Penduduk, Sensus Pertanian dan Sensus Ekonomi. Namun demikian sejak tahun 2008, pendataan Podes dilaksanakan secara independen dari rangkaian kegiatan sensus. Sedangkan yang menjadi unit penelitiannya adalah desa/kelurahan yang diklasifikasikan sebagai pedesaan dan perkotaan di Kabupaten Bandung, Provinsi Jawa Barat.

\subsection{Metode Analisis}

Metode analisis yang akan digunakan dalam penelitian ini adalah dengan menggunakan pemodelan persamaan terstruktur (structural equation modeling, SEM) yang merupakan suatu model yang dikenal mempunyai banyak nama atau istilah, kadang-kadang disebut sebagai analisis struktur kovarians, analisis variabel laten, analisis faktor konfirmatori, atau bahkan sering juga disebut sebagai analisis LISREL (salah nama dari paket perang lunak yang paling terkenal, yang mulai dipopulerkan oleh Joreskog \& Sorbom, 1996). Sebagai hasil dari perkembangan dari pemodelan persamaan simultan dalam ekonometrika yang disertai dengan perkembangan ilmu-ilmu sosial dan psikologi, pemodelan persamaan terstruktur telah menjadi bagian dari salah satu alat yang penting dalam riset-riset akademik. Walaupun teknik ini telah berkembang pesat dan telah banyak diterapkan dalam berbagai bidang penelitian, namun bagi sebagaian peneliti masih belum pasti mengenai definisi mengenai apakah yang disebut dengan pemodelan persamaan terstruktur.

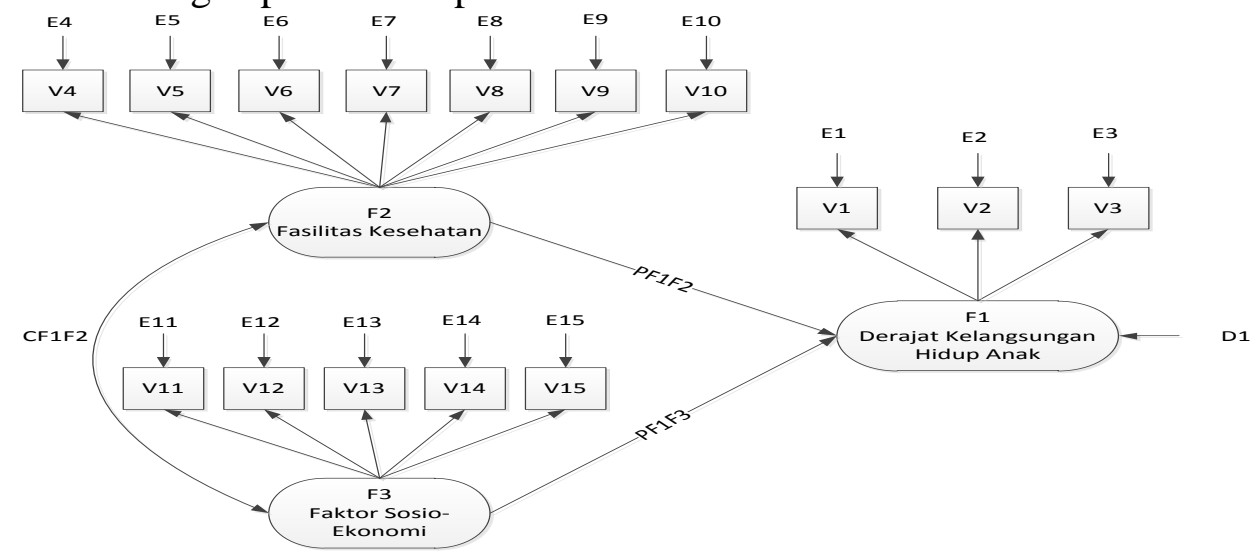

Gambar 1: Model teoritis pengaruh fasilitas kesehatan (F2) dan Faktor Sosio-ekonomi (F3) terhadap derajat kelangsungan hidup anak (F1) 


\subsection{Model Teoritis}

Pada Gambar 1 menyajikan model teoritis yang dikembangkan dalam penelitian ini dalam rangka untuk mengetahui pengaruh faktor fasilitas kesehatan (F2) dan faktor sosial-ekonomi (F3) terhadap derajat kelangsungan hidup anak (F1). Model ini telah disesuaikan dengan data yang tersedia dan disusun dengan tujuan menganalisis dampak sejumlah faktor terhadap kelangsungan hidup anak yang direfleksikan oleh angka kematian bayi (AKB), angka kematian anak (AKA), serta status gizi anak (SGA). Kemudian, dalam penelitian ini akan dikaji faktor-faktor yang berpengaruh terhadap derajat kelangsungan hidup anak tersebut. Adapun faktor-faktor yang menjadi fokus dalam penelitian ini adalah faktor fasilitas kesehatan (yang diukur melalui tujuh indikator) dan faktor sosio-ekonomi (yang diukur melalui lima indikator) sebagaimana yang tersaji pada Tabel 1 .

\subsection{Hipotesis Penelitian}

Hipotesis utama yang akan diuji dalam penelitian ini adalah bahwa faktor-faktor yang berpengaruh terhadap derajat kelangsungan hidup anak yang dikur melalui fasilitas kesehatan kondisi sosio-ekonomi masyarakat untuk wilayah perkotaan dan pedesaan di Kabupaten Bandung adalah sama. Selain itu perlu diketahui pula bahwa hubungan antara AKB dan AKA dengan kelangsungan hidup anak adalah berbanding terbalik, artinya penurunan AKB dan AKA menunjukkan peningkatan terhadap kelangsungan hidup anak begitu pula sebaliknya. Oleh karenanya pengaruh negatif suatu variabel terhadap AKB dan AKA menunjukkan pengaruh yang positif terhadap kelangsungan hidup anak. Sebaliknya, pengaruh positif suatu variabel terhadap AKB dan AKA menunjukkan pengaruh negatif terhadap derajat kelangsungan hidup anak. Sementara itu pengaruh positif pada variabel SGA menunjukkan pengaruh yang positif pula terhadap derajat kelangsungan hidup anak. Dengan demikian hipotesis berikutnya yang akan diuji adalah (1) Fasilitas kesehatan memiliki pengaruh positif terhadap derajat kelangsungan hidup anak; dan (2) Kondisi sosio-ekonomi masyarakat memiliki pengaruh positif terhadap derajat kelangsungan hidup anak.

Tabel 1: Variabel Penelitian (Dimensi dan Indikator)

\begin{tabular}{|c|c|c|c|}
\hline No. & Variabel Laten & & Indikator \\
\hline \multirow[t]{3}{*}{1} & \multirow{3}{*}{$\begin{array}{l}\text { Derajat Kelangsungan } \\
\text { Hidup Anak (F1) }\end{array}$} & V1 & AKA atau Angka Kematian Anak \\
\hline & & $\mathrm{V} 2$ & AKB atau Angka Kematian Bayi \\
\hline & & V3 & Status Gizi Anak \\
\hline \multirow[t]{7}{*}{2} & \multirow[t]{7}{*}{ Fasilitas Kesehatan (F2) } & V4 & Jumlah dokter umum \\
\hline & & V5 & Persentase persalinan yang dibantu oleh tenaga kesehatan \\
\hline & & V6 & Jumlah rumah sakit \\
\hline & & V7 & Jumlah posyandu \\
\hline & & V8 & Jumlah puskesmas \\
\hline & & V9 & Jumlah perawat \\
\hline & & V10 & Jumlah bidan \\
\hline \multirow[t]{5}{*}{3} & \multirow[t]{5}{*}{ Faktor Sosio-Ekonomi (F3) } & V11 & Angka Melek Huruf \\
\hline & & V12 & Rata-rata lama sekolah \\
\hline & & V13 & PDRB \\
\hline & & V14 & Persentase rumah tidak sehat \\
\hline & & V15 & Persentase penduduk miskin \\
\hline
\end{tabular}




\section{Hasil dan Pembahasan}

Sebelum menguraikan hasil analisis model struktural (SEM) terlebih dahulu dilakukan uji kecocokan model (goodness-of-fits). Tujuannya adalah untuk mengetahui apakah model SEM yang dibentuk telah sesuai dengan model teoritisnya. Tabel 2 berikut ini menampilkan beberapa indeks yang umumnya dipakai untuk menentukan kecocokan model dalam analisis model struktural. Model SEM memiliki nilai chisquare yang besar yaitu 560.5037 ( $p$-value < 0.0001), serta nilai RMSA yang juga cukup besar, yaitu sebesar 0.1407. Hal tersebut mengindikasikan bahwa model SEM masih belum cocok. Perlu diketahui bahwa suatu model SEM dikatakan cocok apabila mempunyai nilai RMSA kurang dari 0.08. Sementara itu indeks kecocokan lainnya menunjukkan model yang cocok terhadap data. Sebagai contoh misalnya indeks kecocokan GFI dan AGFI masing-masing memberikan nilai sebesar 0.7261 dan 0.6222. Hal ini menunjukkan bahwa model SEM dapat dikatakan cukup cocok terhadap data. Sedangkan ukuran kecocokan lainnya memberikan nilai yang cukup besar, seperti NFI, NNFI, dan CFI yang masing-masing memberikan nilai di atas 0.8. Dengan demikian model SEM yang dibentuk masih dapat dipertimbangkan untuk digunakan sebagai alat yang baik untuk tujuan penelitian ini.

Tabel 2: Uji Kecocokan Model SEM

\begin{tabular}{l|c|l}
\hline Indeks Kecocokan & Nilai & Kesimpulan \\
\hline Chi-Square & 560.5037 & not fit \\
P-value & $<0.0001$ & \\
RMSEA & 0.1407 & not fit \\
GFI & 0.7261 & close fit \\
AGFI & 0.6222 & close fit \\
NFI & 0.8340 & fit \\
NNFI & 0.8253 & fit \\
CFI & 0.8553 & fit \\
\hline \multicolumn{2}{|c|}{ Sumber: Hasil Pengolan Data megrat SAS }
\end{tabular}

Perlu diketahui bahwa validitas indikator diukur oleh koefisien jalur dibakukan, sedangkan reliabilitas dimensi diukur dengan nilai kuadrat koefisien jalur yang dibakukan. Suatu indikator dinyatakan valid apabila memiliki koefisien jalur dibakukan lebih besar 0.3 atau memiliki nilai t lebih besar 1.96. Sementara itu suatu dimensi dapat dinyatakan reliabel apabila memiliki kuadrat dari koefisien jalur yang dibakukan yang lebih besar 0.7, dan varians ekstrak di atas 0.5. 
Tabel 3: Validitas Indikator dan Reliabilitas Dimensi

\begin{tabular}{|c|c|c|c|c|c|}
\hline \multicolumn{2}{|c|}{ Dimensi dan Indikator } & $\begin{array}{l}\text { Koef. Jalur } \\
\text { Dibakukan }\end{array}$ & $\begin{array}{c}\text { Nilai t } \\
\text { (absolut) }\end{array}$ & Reliabilitas & $\begin{array}{c}\text { Kekeliruan } \\
\text { (Error) }\end{array}$ \\
\hline \multirow{3}{*}{$\begin{array}{c}\text { Derajat } \\
\text { Kelangsungan } \\
\text { Hidup Anak }\end{array}$} & V1 & -0.840 & 16.879 & 0.705 & 0.295 \\
\hline & V2 & -0.850 & 17.181 & 0.722 & 0.278 \\
\hline & V3 & 0.782 & 15.178 & 0.612 & 0.388 \\
\hline \multicolumn{2}{|c|}{ Construct Reliability } & & & 0.864 & \\
\hline \multicolumn{2}{|c|}{ Variance Extracted } & & & & 0.680 \\
\hline \multirow{7}{*}{$\begin{array}{l}\text { Fasilitas } \\
\text { Kesehatan }\end{array}$} & V4 & 0.794 & 15.597 & 0.630 & 0.516 \\
\hline & V5 & 0.822 & 16.437 & 0.675 & 0.285 \\
\hline & V6 & 0.847 & 17.225 & 0.717 & 0.191 \\
\hline & V7 & 0.666 & 12.243 & 0.444 & 0.177 \\
\hline & V8 & 0.718 & 13.517 & 0.515 & 0.238 \\
\hline & V9 & 0.715 & 13.437 & 0.511 & 0.600 \\
\hline & V10 & 0.724 & 13.676 & 0.524 & 0.307 \\
\hline \multicolumn{2}{|c|}{ Construct Reliability } & & & 0.924 & \\
\hline \multicolumn{2}{|c|}{ Variance Extracted } & & & & 0.635 \\
\hline \multirow{5}{*}{$\begin{array}{l}\text { Faktor Sosio- } \\
\text { Ekonomi }\end{array}$} & V11 & 0.680 & 12.561 & 0.462 & 0.488 \\
\hline & V12 & 0.827 & 16.501 & 0.684 & 0.342 \\
\hline & V13 & 0.884 & 18.340 & 0.781 & 0.577 \\
\hline & V14 & 0.893 & 18.643 & 0.797 & 0.558 \\
\hline & V15 & 0.872 & 17.932 & 0.760 & 0.606 \\
\hline \multicolumn{2}{|c|}{ Construct Reliability } & & & 0.870 & \\
\hline \multicolumn{2}{|c|}{ Variance Extracted } & & & & 0.575 \\
\hline
\end{tabular}

Dari hasil perhitungan diketahui bahwa semua koefisien jalurnya adalah signifikan karena mempunyai nilai $t>1.96$, sehingga indikator yang digunakan dalam penelitian ini dapat dinyatakan valid. Begitu pula halnya dengan semua dimensi dalam penelitian ini dinyatakan reliabel, karena memiliki nilai reliabilitas konstruk di atas 0.7 dan varians ekstrak di atas 0.5. Dimensi yang mempunyai reliabilitas konstruk yang paling tinggi adalah dimensi fasilitas kesehatan (F2), kemudian diikuti oleh dimensi faktor sosio-ekonomi (F3), serta dimensi derajat kelangsungan hidup anak (F1). Ketiga dimensi yang diamati dalam penelitian ini masing-masing mempunyai nilai reliabilitas konstruk sebesar $0.924,0.870$, serta 0.864 .

Berdasarkan model pengukuran tersebut dapat dijelaskan bahwa indikator yang memberikan kontribusi terbesar dalam memprediksi dimensi F1 adalah indikator V2, yaitu indikator yang berkaitan dengan Angka Kematian Bayi (AKB), sebesar 72.25\% dengan kekeliruan sebesar $27.8 \%$. Kemudian, indikator yang memberikan kontribusi terbesar kedua dalam memprediksi F1 adalah V1, yaitu indikator yang berkaitan dengan Angka Kematian Anak (AKA) sebesar 70.56\% dengan kekeliruan sebesar $29.5 \%$. Sedangkan indikator V3 atau status gizi anak merupakan indikator yang memberikan kontribusi paling kecil dalam memprediksi derajat kelangsungan hidup anak, yaitu sebesar $61.15 \%$ dengan kekeliruan sebesar $38.8 \%$. 


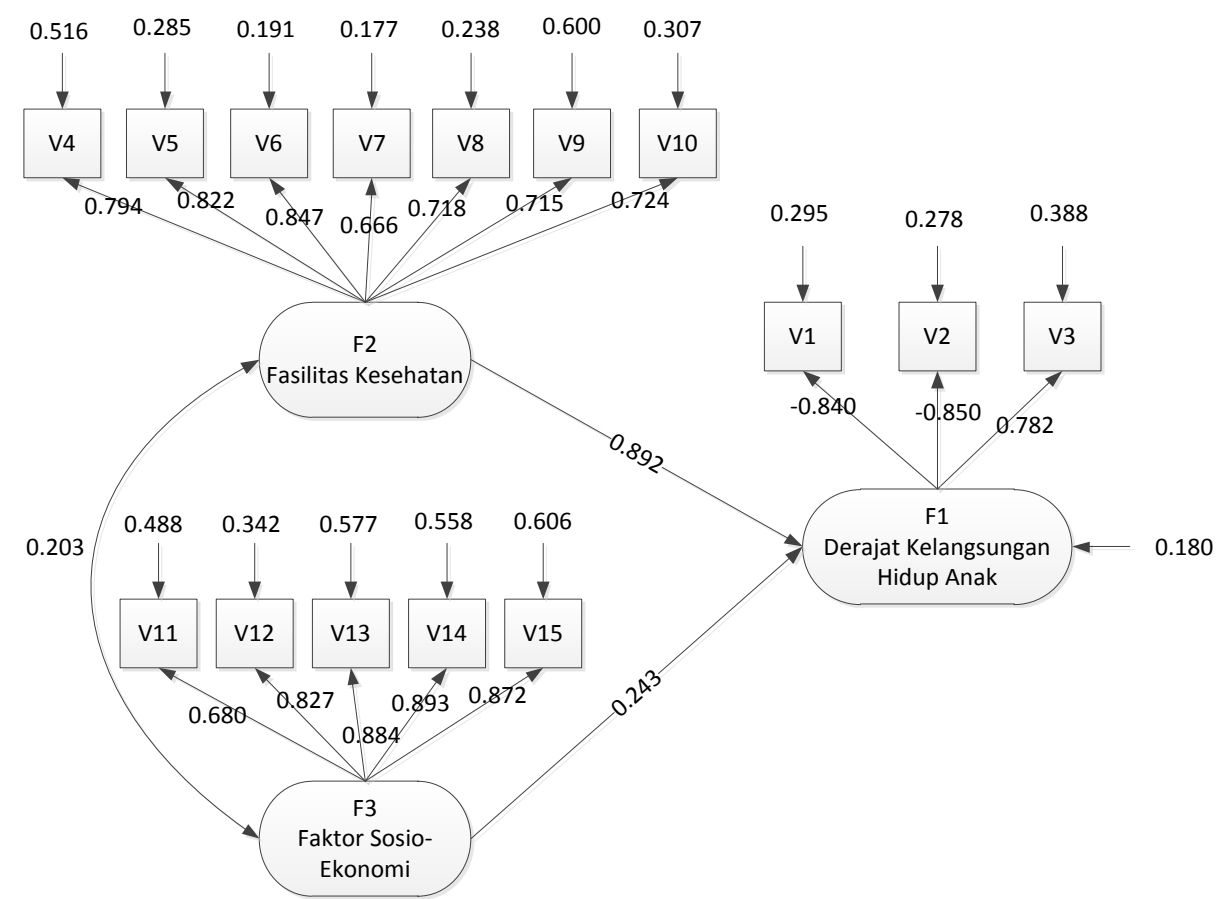

\section{Gambar 2: Model Pengukuran Pengaruh Fasilitas Kesehatan dan Faktor Sosio-Ekonomi terhadap Derajat Kelangsungan Hidup Anak}

Berdasarkan model pengukuran tersebut dapat dijelaskan bahwa dua buah indikator yang memberikan kontribusi terbesar kesatu dan kedua dalam memprediksi dimensi F2 adalah indikator jumlah rumah sakit (V6) dan persentase persalinan yang dibantu oleh tenaga kesehatan (V5). Kedua indikator tersebut masing-masing memberikan kontribusi sebesar $71.74 \%$ dan $67.57 \%$, dengan kekeliruan masing-masing sebesar $19.1 \%$ dan $28.5 \%$. Sedangkan indikator yang memberikan kontribusi paling kecil terhadap dimensi fasilitas kesehatan adalah jumlah posyandu (V7) dengan kontribusi sebesar $44.36 \%$ dan kekeliruannya sebesar $17.7 \%$. Sementara itu indikator lainnya seperti jumlah dokter umum (V4), jumlah puskesmas (V8), jumlah perawat (V9), serta jumlah bidan (V10) masing-masing memberikan kontribusi yang cukup, yaitu berkisar antara 50\% sampai dengan $60 \%$.

Berdasarkan model pengukuran tersebut dapat dijelaskan bahwa terdapat tiga buah indikator yang memberikan kontribusi yang besar dalam memprediksi dimensi F3, yaitu di atas $75 \%$. Ketiga indikator tersebut adalah persentase rumah tidak sehat (V14), PDRB (V13), dan persentase penduduk miskin (V15), dimana ketiga indikator tersebut masing-masing memberikan kontribusi sebesar $79.75 \%, 78.15 \%$, dan $76.04 \%$. Sementara itu indkator rata-rata lama sekolah (V12) memberikan kontribusi sebesar 68.39\% dalam memprediksi dimensi F3 dengan kekeliruan sebesar 34.2\%. Sedangkan indikator angka melek huruf (V11) merupakan indikator yang memberikan kontribusi paling kecil terhadap dimensi F3, yaitu hanya sebesar $46.24 \%$ dengan kekeliruan sebesar $48.8 \%$.

Setelah dibentuk model pengukuran untuk masing-masing dimensi yang dikaji dalam penelitian ini, maka langkah selanjutnya adalah mengidentifikasi faktor-faktor yang berpengaruh terhadap derajat kelangsungan hidup anak (F1). Hal ini dapat dilakukan melalui model terstrktur yang dinyatakan dalam gambar berikut ini: 


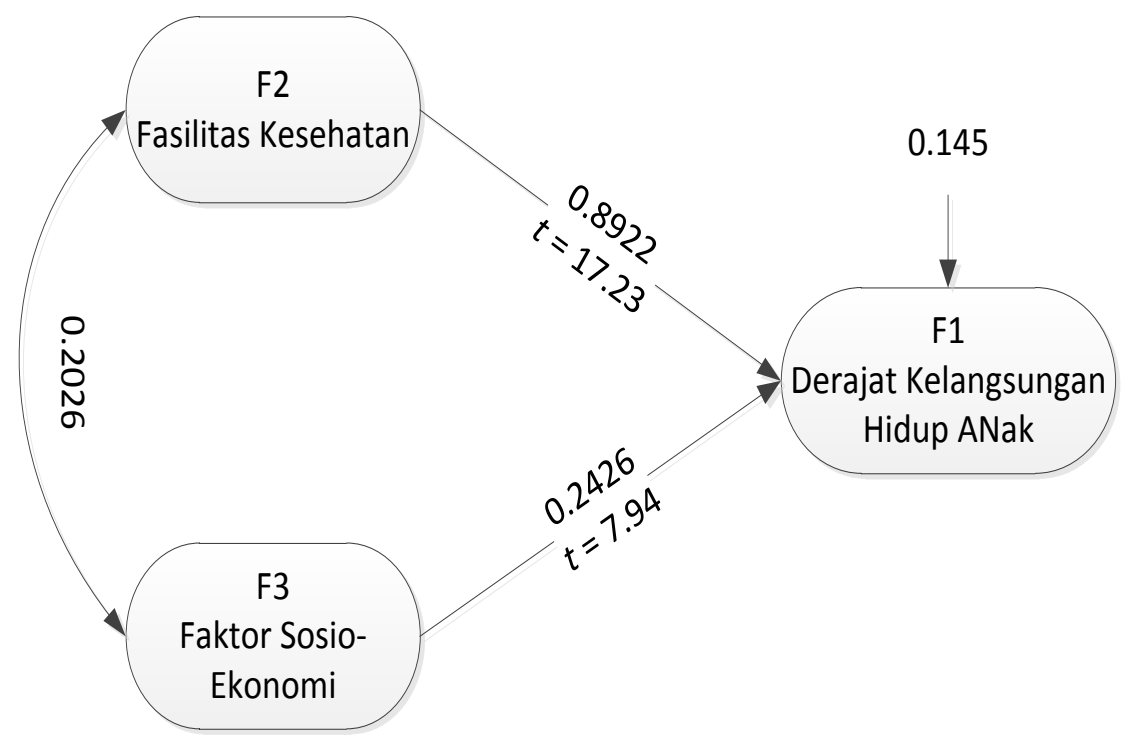

\section{Gambar 3: Model Terstruktur Pengaruh Fasilitas Kesehatan dan Faktor Sosio-Ekonomi terhadap Derajat Kelangsungan Hidup Anak}

Model struktural derajat kelangsungan hidup anak (F1) yang dipengaruhi oleh fasilitas kesehatan (F2) dan faktor sosio-ekonomi (F3) dapat dinyatakan dalam bentuk persamaan berikut:

$$
\mathrm{F} 1=0.8922 \mathrm{~F} 2+0.2426 \mathrm{~F} 3+0.180
$$

Hasil analisis tersebut menunjukkan bahwa faktor yang memberikan pengaruh secara langsung yang terbesar terhadap derajat kelangsungan hidup anak adalah fasilitas kesehatan (dengan nilai koefisien sebesar 0.8922) sebesar 79.60\%. Sedangkan dimensi faktor sosio-ekonomi memberikan pengaruh secara langsung yang relatif cukup kecil terhadap derajat kelangsungan hidup anak hanya sebesar 5.89\% (nilai koefisien sebesar 0.2426). Perlu diketahui bahwa kedua dimensi, F2 dan F3, masing-masing memberikan nilai-t sebesar 17.23 dan 7.94. Hal ini menunjukkan bahwa kedua dimensi tersebut (fasilitas kesehatan dan faktor sosio-ekonomi) merupakan faktor-faktor yang secara statistik signifikan berpengaruh terhadap derajat kelangsungan hidup anak. Besar pengaruh total dari dimensi fasilitas kesehatan dan faktor sosio-ekonomi terhadap derajat kelangsungan hidup anak adalah sebesar $85.5 \%$, sedangkan pengaruh luarnya adalah sebesar $14.5 \%$.

\section{Kesimpulan}

Model teoritis yang diajukan dalam penelitian ini masih dapat dipertimbangkan untuk digunakan sebagai alat yang baik untuk tujuan penelitian ini, karena memiliki beberapa ukuran kecocokan model (seperti NFI, NNFI, dan CFI) yang memenuhi kriteria sebagai model yang dianggap cocok. Semua koefisien jalurnya adalah signifikan karena mempunyai nilai $t>1.96$, sehingga indikator yang digunakan dalam penelitian ini dapat dinyatakan valid. Begitu pula halnya dengan semua dimensi dalam penelitian ini dinyatakan reliabel, karena memiliki nilai reliabilitas konstruk di atas 0.7 dan varians ekstrak di atas 0.5 .

Indikator yang memberikan kontribusi terbesar dalam memprediksi dimensi F1 adalah indikator V2, yaitu indikator yang berkaitan dengan Angka Kematian Bayi (AKB), sebesar $72.25 \%$ dengan kekeliruan sebesar 27.8\%. Kemudian, indikator yang 
memberikan kontribusi terbesar kedua dalam memprediksi $\mathrm{F} 1$ adalah V1, yaitu indikator yang berkaitan dengan Angka Kematian Anak (AKA) sebesar 70.56\% dengan kekeliruan sebesar 29.5\%. Sedangkan indikator V3 atau status gizi anak merupakan indikator yang memberikan kontribusi paling kecil dalam memprediksi derajat kelangsungan hidup anak, yaitu sebesar $61.15 \%$ dengan kekeliruan sebesar 38.8\%.

Dua buah indikator yang memberikan kontribusi terbesar kesatu dan kedua dalam memprediksi dimensi F2 adalah indikator jumlah rumah sakit (V6) dan persentase persalinan yang dibantu oleh tenaga kesehatan (V5). Kedua indikator tersebut masing-masing memberikan kontribusi sebesar $71.74 \%$ dan $67.57 \%$, dengan kekeliruan masing-masing sebesar $19.1 \%$ dan 28.5\%. Sedangkan indikator yang memberikan kontribusi paling kecil terhadap dimensi fasilitas kesehatan adalah jumlah posyandu (V7) dengan kontribusi sebesar $44.36 \%$ dan kekeliruannya sebesar $17.7 \%$. Sementara itu indikator lainnya seperti jumlah dokter umum (V4), jumlah puskesmas (V8), jumlah perawat (V9), serta jumlah bidan (V10) masing-masing memberikan kontribusi yang cukup, yaitu berkisar antara 50\% sampai dengan $60 \%$.

Terdapat tiga buah indikator yang memberikan kontribusi yang besar dalam memprediksi dimensi F2, yaitu di atas 75\%. Ketiga indikator tersebut adalah persentase rumah tidak sehat (V14), PDRB (V13), dan persentase penduduk miskin (V15), dimana ketiga indikator tersebut masing-masing memberikan kontribusi sebesar $79.75 \%$, $78.15 \%$, dan 76.04\%. Sementara itu indkator rata-rata lama sekolah (V12) memberikan kontribusi sebesar $68.39 \%$ dalam memprediksi dimensi F3 dengan kekeliruan sebesar $34.2 \%$. Sedangkan indikator angka melek huruf (V11) merupakan indikator yang memberikan kontribusi paling kecil terhadap dimensi F3, yaitu hanya sebesar $46.24 \%$ dengan kekeliruan sebesar $48.8 \%$.

Faktor yang memberikan pengaruh secara langsung yang terbesar terhadap derajat kelangsungan hidup anak adalah fasilitas kesehatan (dengan nilai koefisien sebesar 0.8922 ) sebesar 79.60\%. Sedangkan dimensi faktor sosio-ekonomi memberikan pengaruh secara langsung yang relatif cukup kecil terhadap derajat kelangsungan hidup anak hanya sebesar 5.89\% (nilai koefisien sebesar 0.2426).

\section{Daftar Pustaka}

Badan Perencanaan Pembangunan Nasional (2009). Kajian evaluasi pembangunan sektoral: Faktor-Faktor yang mempengaruhi kelangsungan hidup anak. Jakarta: Bappenas.

Badan Perencanaan Pembangunan Nasional (2010). Laporan Pencapaian Tujuan Pembangunan Milenium di Indonesia 2010. Jakarta: Kementerian Perencanaan Pembangunan Nasional/Badan Perencanaan Pembangunan Nasional (BAPPENAS)

Badan Pusat Statistik. 2007. Survei Demografi Kesehatan Indonesia. Jakarta: BPS.

Badan Pusat Statistik. 2010. Peraturan Kepala Badan Pusat Statistik tentang Klasifikasi Pedesaan dan Perkotaan di Indonesia. Cetakan II. Jakarta: BPS.

Bollen, K. A. (1989). Structural equations with latent variables. New York: John Wiley and Son.

Filmer, D. (2003). Determinants of Health \& Education Outcomes Background Note for World Development Report 2004: Making Service Work for Poor People. World Bank.

Joreskog, K. J., \& Sorbom, D. (1996). LISREL 8: Users reference guide. Chicago: SSI Scientific Software International, Inc. 
242 | Nusar Hajarisman, et al.

Mosley, W. Henry and Chen, Lincoln. C. 1984. An analytical framework for the study of child survival in developing countries. Population \& Development Review, Volume 10, Issue Supplement; Child Survival: Strategy For Research. 25-45. 